The Mathematics of

Egypt,

Mesopotamia,

China,

India, and

Islam

A Sourcebook 



\section{The Mathematics of}

Egypt,

Mesopotamia,

China,

India, and

Islam

A Sourcebook

Victor Katz, Editor

Annette Imhausen

Eleanor Robson

Joseph Dauben

Kim Plofker

J. Lennart Berggren 
Copyright $(\mathcal{O} 2007$ by Princeton University Press

Published by Princeton University Press, 41 William Street, Princeton, New Jersey 08540

In the United Kingdom: Princeton University Press, 3 Market Place, Woodstock, Oxfordshire OX20 1SY

All Rights Reserved

Library of Congress Cataloging-in-Publication Data

The mathematics of Egypt, Mesopotamia, China, India, and Islam: a sourcebook/Victor Katz, editor.

p. cm.

Includes bibliographical references and index.

ISBN-13: 978-0-691-11485-9 (hardcover: alk. paper)

ISBN-10: 0-691-11485-4 (hardcover: alk. paper)

1. Mathematics, Ancient-Sources. 2. Mathematics-History-Sources.

I. Katz, Victor J.

QA22.M3735 2007

510.9-dc22

2006030851

British Library Cataloging-in-Publication Data is available

This book has been composed in Minion and Univers

Printed on acid-free paper. $\infty$

press.princeton.edu

Printed in the United States of America 